\title{
Serum zinc levels and predictors of severity of acute lower respiratory tract infections in children under five years of age
}

\author{
Shisira Philip ${ }^{1}$, *Jessie Jose ${ }^{2}$, Kalyani Pillai ${ }^{3}$, Vadakkoottu Krishnan Parvathy ${ }^{4}$
}

Sri Lanka Journal of Child Health, 2021; 50(4): 630-636

DOI: http://doi.org/10.4038/sljch.v50i4.9852

\begin{abstract}
Background: Zinc has a central role in immunity and body`s response to infection. The detrimental effects of zinc deficiency on the immune system can lead to a worse outcome in pneumonia and other infections. There has been renewed interest in zinc in the wake of the SARS Coronavirus 2 pandemic.
\end{abstract}

Objectives: To estimate the serum zinc levels in children with acute lower respiratory infection (ALRI) and determine its association with respiratory rate, heart rate and oxygen saturation in room air.

Method: This hospital based descriptive study included 40 children admitted with varying degrees of severity of ALRI.

Results: Nineteen (47.5\%) cases presented as wheeze-associated lower respiratory infection (WALRI) and bronchiolitis, $12(30 \%)$ presented as pneumonia, $7(17.5 \%)$ as severe pneumonia and 2 $(5 \%)$ as very severe pneumonia. The mean serum zinc level was statistically different among these groups of children $(p=0.0001)$. The mean serum zinc level in children with WALRI / bronchiolitis was $63.0532 \pm 5.6283 \mu \mathrm{g} / \mathrm{dl}$ while in children with pneumonia, severe pneumonia and very severe pneumonia the mean serum zinc levels were $48.5817 \pm 1.7937 \mu \mathrm{g} / \mathrm{dl}, 38.1043 \pm 3.8443 \mu \mathrm{g} / \mathrm{dl}$ and $36.305 \pm 2.86378 \mu \mathrm{g} / \mathrm{dl}$ respectively. Children with tachypnoea, tachycardia and low oxygen saturation levels had lower mean serum zinc levels of $44.579 \mu \mathrm{g} / \mathrm{dl}(\mathrm{p}=0.0001), 44.1113 \mu \mathrm{g} / \mathrm{dl}(\mathrm{p}=0.0001)$

\footnotetext{
${ }^{1}$ Postgraduate in Paediatrics, ${ }^{2}$ Assistant Professor, ${ }^{3}$ Professor, ${ }^{4}$ Professor and Head, Department of Paediatrics, Amala Institute of Medical Sciences, Thrissur, Kerala, India

*Correspondence: jessiejose77@gmail.com
}

https://orcid.org/0000-0003-0697-0238

(Received on 13 October 2020: Accepted after revision on 20 November 2020)

The authors declare that there are no conflicts of interest.

Personal funding was used for the project.

Open Access Article published under the Creative Commons Attribution CC-BY (c) (i) License and $54.3073 \mu \mathrm{g} / \mathrm{dl} \quad(\mathrm{p}=0.009)$ respectively which were statistically significant.

Conclusions: The mean serum zinc level was significantly low in children with tachypnoea, tachycardia and low oxygen saturation levels which are predictors of severe illness. Significantly low mean serum zinc levels were observed in children with different grades of pneumonia when compared to children with WALRI / bronchiolitis and in children with severe pneumonia when compared to those with pneumonia.

(Key words: Preschool children, Pneumonia, Tachypnoea, Tachycardia, Zinc)

\section{Introduction}

The current global pandemic of Covid-19 has rekindled interest in the protective and therapeutic roles of zinc, a micronutrient, in pneumonia. Though data is limited, zinc has been potentially used as supportive therapy in SARS CoV-2 pneumonia because of its direct antiviral effect, anti-inflammatory properties and modulation of antibacterial and antiviral immunity ${ }^{1}$ Zinc regulates intracellular signalling pathways in immune cells and has a key role in both innate as well as adaptive immune responses in the body. Deficiency of zinc causes impaired phagocyte function, reduction in lymphocytes and $\mathrm{T} 4+/ \mathrm{T} 8+$ ratio and diminished immunoglobulin and interleukin-2 production which can lead to a potentially worse outcome in infections ${ }^{2}$. The incidence of pneumonia worldwide is over 1400 cases per 100,000 children, with the highest incidence in South Asia (2500 cases per 100,000 children) followed by West and Central Africa $(1620 \text { cases per } 100,000 \text { children })^{3}$. The results of a critical review of randomised control trials studying the effects of nutritional interventions and breastfeeding promotion on acute lower respiratory infection (ALRI) morbidity and mortality, undertaken by Roth DE, et $a l^{4}$ showed that zinc supplementation in zinc deficient populations prevented around $25 \%$ of episodes of ALRI.

\section{Objectives}

To estimate the serum zinc levels in children with ALRI and determine its association with respiratory rate, heart rate and oxygen saturation in room air. 


\section{Method}

This was a descriptive study performed on 40 children aged 1-5 years admitted with ALRI to the paediatric department of a tertiary care hospital over a period of one year and 7 months. Children were recruited into the study based on clinical symptoms and abnormal lower respiratory tract signs including abnormal chest auscultatory findings. Clinical diagnoses of bronchiolitis, wheeze-associated lower respiratory infection (WALRI) and pneumonia were made based on symptoms and physical examination findings by the primary investigator. Children having pneumonia were further categorised into pneumonia, severe pneumonia or very severe pneumonia based on clinical features according to the revised WHO classification of pneumonia in children $^{5}$. Radiological analysis of the cases was not considered for the grading of severity. Children with chronic illnesses, inborn errors of metabolism, malnutrition (IAP classification of protein energy malnutrition: weight for age $<80 \%$ ) and those receiving zinc supplements were not included in the study.

Setting a confidence interval of $95 \%$, a sample size of 40 was estimated using a standard deviation of $25.3^{6}$ and a relative precision of $10 \%$ of the mean.

Data were collected from the patients regarding their nutritional status, vital functions on admission, including temperature, respiratory rate $(\mathrm{RR})$, heart rate (HR), oxygen saturation $(\mathrm{SaO} 2)$ in room air, clinical features and recorded on data collection forms.

Tachypnoea was defined as a respiratory rate $\geq 40$ / minute for the children in the study group according to WHO guidelines ${ }^{5}$. The normal range of heart rate for children 1-3 years of age was taken as 70-110/minute and for children 3-5 years as 65$110 /$ minute $^{7}$. A heart rate $>110 /$ minute was taken as tachycardia. The normal range of $\mathrm{SaO} 2$ at sea level is $97-99 \%$, with a lower limit of $94 \%$. $\mathrm{SaO} 2<90 \%$ indicates hypoxaemia ${ }^{8}$.

Two ml of blood was drawn by venepuncture after properly preparing the site with povidone-iodine and alcohol, within 24 hours of admission. Sample taken was sent for serum zinc level analysis by the Inductively Coupled Plasma Mass Spectrometry (ICPMS) method. The normal reference value of serum zinc concentration for males and females are $75-291 \mu \mathrm{g} / \mathrm{dl}$ and $65-256 \mu \mathrm{g} / \mathrm{dl}$ respectively. The cut off level of serum zinc concentration for defining zinc deficiency was taken as less than $65 \mu \mathrm{g} / \mathrm{dl}$ for males and females in this age group ${ }^{9}$.
Ethical issues: Approval for the study was obtained from the Institutional Ethics Committee of Amala Institute of Medical Sciences, Thrissur (Registration number ECR/653/Inst/ KL/2014) prior to the beginning of the study. Written informed consent was obtained from the parents of all the children who participated in the study.

Statistical analysis: The data obtained was coded and entered in Microsoft Excel Sheet and analysed using the statistical software Statistical Package for Social Sciences (SPSS) version 23. The results are expressed in percentage and proportions. The statistical technique independent t-test was used for analysis.

\section{Results}

Out of 40 cases included in study, 21 were males and 19 were females. Mean age of children in the study group was $2.650 \pm 1.4901$ years. Children with WALRI / bronchiolitis constituted 19 (47.5\%) cases while $21(52.5 \%)$ children had pneumonia. Children with pneumonia were categorised into pneumonia $12(30 \%)$ cases, severe pneumonia 7 $(17.5 \%)$ cases and very severe pneumonia $2(5 \%)$ cases.

In our study group the mean respiratory rate was $30.53 \pm 2.563$ /minute in children with WALRI / bronchiolitis, $45.83 \pm 10.461 /$ minute in those with pneumonia, $51.14 \pm 7.647 /$ minute in those with severe pneumonia and $50 \pm 14.142$ /minute in those with very severe pneumonia. The mean respiratory rates were significantly different between the four groups of children in the study population $(p=0.0001)$. The mean heart rates were also significantly different between the subsets of children in the study group $(\mathrm{p}=0.002)$. The mean heart rate in children with WALRI/bronchiolitis was $104.63 \pm 11.927 /$ minute, in pneumonia 114.17 $\pm 15.643 /$ minute, in severe pneumonia $123.71 \pm$ $16.790 /$ minute and in very severe pneumonia $140 \pm$ $0.2 /$ minute respectively. Significantly different mean $\mathrm{SaO} 2$ levels $(\mathrm{p}=0.0001)$ also were found between the children with WALRI / bronchiolitis (mean SaO2 level $99.8 \pm 0.501 \%$ ), pneumonia (mean $\mathrm{SaO} 2$ level $98.33 \pm 1.826 \%$ ), severe pneumonia (mean $\mathrm{SaO} 2$ level $95.71 \pm 3.773 \%$ ) and very severe pneumonia (mean $\mathrm{SaO} 2$ level $96.00 \pm$ $5.657 \%$ ). None of the children in the study population had hypoxaemia with oxygen saturation $<90 \%$ on pulse oximeter, in room air.

Table 1 shows the respiratory rates of children in the study group and their mean serum zinc levels. 
Table 1: Respiratory rates of children in the study group and their mean serum zinc levels

\begin{tabular}{|c|c|c|c|c|}
\hline $\begin{array}{c}\text { Respiratory rate } \\
\text { per minute }\end{array}$ & $\begin{array}{c}\text { Number of } \\
\text { children }\end{array}$ & $\begin{array}{c}\text { Mean serum zinc } \\
\text { level } \boldsymbol{\mu g} / \mathbf{d l}\end{array}$ & $\begin{array}{c}\text { Standard } \\
\text { deviation }\end{array}$ & $\begin{array}{c}\text { p value } \\
\text { (T test) }\end{array}$ \\
\hline$<40$ & 19 & 63.0532 & 5.62830 & 0.0001 \\
\hline$\geq 40$ & 21 & 43.9200 & 6.10646 & \\
\hline
\end{tabular}

It was seen that children who developed tachypnoea, with a respiratory rate $>40$ /minute had lower mean serum zinc levels compared to those who did not have tachypnoea, which was statistically significant $(\mathrm{p}<0.0001)$.

Table 2 shows the heart rates of children in the study group and their mean serum zinc levels

Table 2: Heart rates of children in the study group and their mean serum zinc levels

\begin{tabular}{|c|c|c|c|c|c|}
\hline $\begin{array}{c}\text { Heart rate per } \\
\text { minute }\end{array}$ & No. of children & $\begin{array}{c}\text { Mean serum zinc } \\
\text { level } \boldsymbol{\mu g} / \mathbf{d l}\end{array}$ & $\begin{array}{c}\text { Standard } \\
\text { deviation }\end{array}$ & T test value & p value \\
\hline$<120$ & 24 & 58.9396 & 9.90204 & 5.299 & 0.0001 \\
\hline $120-150$ & 16 & 44.1113 & 6.33299 & & \\
\hline
\end{tabular}

Similarly, children with higher heart rates in the study group had lower mean serum zinc levels when compared to children who had normal heart rates $(\mathrm{p}=0.0001)$.
Table 3 shows the oxygen saturation $(\mathrm{SaO} 2)$ levels in room air of children in study group and their mean serum zinc levels.

Table 3: Oxygen saturation levels in room air of children in study group and their mean serum zinc levels

\begin{tabular}{|l|l|l|l|c|c|}
\hline $\begin{array}{c}\text { SaO2 level in } \\
\text { room air \% }\end{array}$ & No. of children & $\begin{array}{c}\text { Mean serum zinc } \\
\text { level } \boldsymbol{\mu g} / \mathbf{d l}\end{array}$ & $\begin{array}{c}\text { Standard } \\
\text { deviation }\end{array}$ & T test value & p value \\
\hline$\leq 94$ & 3 & 36.9867 & 3.31212 & 2.766 & 0.009 \\
\hline$>94$ & 37 & 54.3073 & 10.68897 & & \\
\hline
\end{tabular}

SaO2: Oxygen saturation

A comparison of the mean serum zinc levels between children with $\mathrm{SaO} 2 \leq 94 \%$ and those with $\mathrm{SaO} 2$ level $>94 \%$ in room air showed statistically significant lower mean serum zinc level in the group with lower oxygen saturation levels $(\mathrm{p}=$ $0.009)$.

Among the children with severe ( 7 children) and very severe ( 2 children) pneumonia, convulsions were noted in 2 children, inability to drink in 2 children and stridor and altered sensorium in one of the two children with very severe pneumonia.
Mean serum zinc level in our study was $53.0083 \pm$ $11.286 \mu \mathrm{g} / \mathrm{dl}$. Mean serum zinc level in children with WALRI / bronchiolitis was $63.0532 \pm$ $5.6283 \mu \mathrm{g} / \mathrm{dl}$, in children with pneumonia $48.5817 \pm$ $1.7937 \mu \mathrm{g} / \mathrm{dl}$, in severe pneumonia $38.1043 \pm$ $3.8443 \mu \mathrm{g} / \mathrm{dl}$ and in very severe pneumonia 36.305 $\pm 2.86378 \mu \mathrm{g} / \mathrm{dl}$ as shown in Table 4 . Statistically significant difference in mean serum zinc level $(p=0.0001)$ was observed between the mean serum zinc levels in children with WALRI / bronchiolitis, pneumonia, severe pneumonia and very severe pneumonia.

Table 4: Mean zinc levels of children with lower respiratory tract infection

\begin{tabular}{|l|c|c|c|}
\hline \multirow{2}{*}{$\begin{array}{l}\text { Lower respiratory tract } \\
\text { infection }\end{array}$} & Mean & Standard deviation & \\
\cline { 2 - 3 } & 63.0532 & 5.62830 & \\
\\
\cline { 2 - 3 } WALRI/Bronchiolitis & 48.5817 & 1.79377 & \multirow{2}{*}{0.0001} \\
\hline Pneumonia & 38.1043 & 3.84434 & \\
\hline Severe pneumonia & 36.3050 & 2.86378 & \\
\hline
\end{tabular}

WALRI- wheeze associated lower respiratory infection

On further analysis (Tukey`s post-hoc test), given below in Table 5, the mean serum zinc levels were found to be statistically significant when comparing the levels of children with WALRI / bronchiolitis with those having pneumonia $(p=0.00)$ or severe pneumonia $(\mathrm{p}=0.00)$. The mean serum zinc levels were also observed to be significantly low when comparing the levels in children with pneumonia with those of severe pneumonia $(p=0.00)$ but not significant when comparing children with severe and very severe pneumonia $(\mathrm{p}=0.957)$. 
Table 5: Comparison of mean serum zinc levels among the groups of children with ALRI

\begin{tabular}{|l|l|c|r|c|}
\hline $\begin{array}{c}\text { (I) LRTI } \\
\text { subgroups }\end{array}$ & \multicolumn{1}{|c|}{$\begin{array}{c}\text { Mean difference of serum } \\
\text { zinc level (I-J) }\end{array}$} & Standard error & P value \\
\hline \multirow{3}{*}{$\begin{array}{c}\text { WALRI/ } \\
\text { Bronchiolitis }\end{array}$} & Pneumonia & $14.47149^{*}$ & 1.62883 & 0.000 \\
\cline { 2 - 5 } & Severe pneumonia & $24.94887^{*}$ & 1.95309 & 0.000 \\
\cline { 2 - 5 } & Very severe pneumonia & $26.74816^{*}$ & 3.28383 & 0.000 \\
\hline \multirow{4}{*}{ Pneumonia } & WALRI/ Bronchiolitis & $-14.47149^{*}$ & 1.62883 & 0.000 \\
\cline { 2 - 5 } & Severe Pneumonia & $10.47738^{*}$ & 2.10087 & 0.000 \\
\cline { 2 - 5 } & Very severe Pneumonia & $12.27667^{*}$ & 3.37381 & 0.005 \\
\hline \multirow{4}{*}{ Severe pneumonia } & WALRI/ Bronchiolitis & $-24.94887^{*}$ & 1.95309 & 0.000 \\
\cline { 2 - 5 } & Pneumonia & $-10.47738^{*}$ & 2.10087 & 0.000 \\
\cline { 2 - 5 } & Severe Pneumonia & 1.79929 & 3.54176 & 0.957 \\
\hline \multirow{2}{*}{$\begin{array}{l}\text { Very severe } \\
\text { pneumonia }\end{array}$} & WALRI/ Bronchiolitis & $-26.74816^{*}$ & 3.28383 & 0.000 \\
\cline { 2 - 5 } & Pneumonia & $-12.27667^{*}$ & 3.37381 & 0.005 \\
\cline { 2 - 5 } & Severe Pneumonia & -1.79929 & 0.957 \\
\hline
\end{tabular}

LRTI: Lower respiratory tract infection

\section{Discussion}

In this study, we found that out of 40 cases of ALRI studied, males (21 cases 52.5\%) outnumbered females (19 cases $47.5 \%$ ). An analysis of the mean serum zinc level of males and females in the present study showed no statistically significant difference between the mean serum zinc levels of males $(53.13 \pm 11.96)$ and females $(52.86 \pm 10.81)(\mathrm{p}$ $=0.941)$ which is similar to the findings obtained in studies by Paneerselam $\mathrm{R}$, et $a l^{10}$, Kumar DE, et $a l^{11}$ and Hussain AM, et $a l^{12}$.

In the present study, $50 \%$ of children belonged to the age group $12-30$ months, and $50 \%$ belonged to the age group 30 to 60 months. The mean age of the children in the study group was 31.075 months. The mean serum zinc level in children $\geq 30$ months $(51.92 \pm 11.10)$ was lower when compared to the level in children $<30$ months $(54.09 \pm 11.64)$ but it was not statistically significant $(\mathrm{p}=0.551)$. This contrasts with the study by Hussain AM, et $a l^{12}$ where lower mean serum zinc levels were noted in infants than in older children, but the difference was not statistically significant. Other studies by Kumar S, et $a l^{13}$ and Kumar DE, et $a l^{11}$ have shown that the mean serum zinc levels of children did not vary significantly with age.

In the present study, a comparison of the mean serum zinc levels between children with tachypnoea ( $\mathrm{RR}>40 / \mathrm{min}$ ) and respiratory distress, and children without tachypnoea showed a statistically significant lower mean zinc level ( $p$ $<0.001$ ) in children with respiratory distress. This is similar to the study by Rady HI, et $a l^{6}$ where they found serum zinc levels were lower in children with higher grades of respiratory distress and those who required respiratory support compared to patients who were not in respiratory distress. Similarly, children with tachycardia also had significantly lower mean serum zinc levels compared to children without tachycardia $(p<0.001)$. Mean serum zinc levels of children with
$\mathrm{SaO} 2$ levels $\leq 94 \%$ were significantly less $(p<0.001)$ as against the mean serum zinc level of children with higher $\mathrm{SaO} 2$ levels. Similar findings have been reported in the study by Shivalingaiah $\mathrm{M}$, et $a l^{14}$. Children who developed increasing severity of illness with respect to tachypnoea, tachycardia and decreased $\mathrm{SaO} 2$ levels had lower mean serum zinc levels in our study.

The mean serum zinc level in children with WALRI / bronchiolitis was $63 \pm 5.6 \mu \mathrm{g} / \mathrm{dl}$, with pneumonia $48.58 \pm 1.793 \mu \mathrm{g} / \mathrm{dl}$, with severe pneumonia $38.10 \pm 3.844 \mu \mathrm{g} / \mathrm{dl}$ and in children with danger signs and very severe pneumonia $36.3 \pm 2.863 \mu \mathrm{g} / \mathrm{dl}$. The mean serum zinc level was significantly different among the above mentioned groups of children $(\mathrm{p}=0.0001)$. The mean serum Zinc levels were found to be statistically significant when the levels in children with WALRI / bronchiolitis were compared with those having pneumonia $(p=0.00)$, severe pneumonia $(\mathrm{p}=0.00)$ or very severe pneumonia $(p=0.00)$. The mean serum zinc level was also observed to be significantly low when the levels in children with severe pneumonia were compared with those of pneumonia $(p=0.00)$ but not significant when compared with the level in children with very severe pneumonia $(p=0.957)$.

Several studies have reported low serum zinc levels in children with pneumonia ${ }^{10,15,16}$ and significantly lower values in children with severe pneumonia ${ }^{12,13,17,18}$. According to a cross-sectional hospital-based study by Ibraheem RM et $a l^{16}$, the mean serum zinc level in children 2 months to 5 years of age with ALRI was $18.7 \pm 11.8 \mu \mathrm{g} / \mathrm{dl}$ which was significantly lower compared to $53.1 \pm$ $18.5 \mu \mathrm{g} / \mathrm{dl}$ recorded in the controls $(\mathrm{p}=0.001)$. Fifty cases of severe pneumonia and fifty cases of healthy control group of children of same age, sex and nutritional status were compared by Pushpa et $a l^{17}$; they found that low serum zinc levels were present even in well-nourished children suffering from severe pneumonia (mean $=184.92 \pm$ 
$44.11 \mu \mathrm{g} / \mathrm{dl}$ ) as compared to controls (mean = $206.76 \pm 47.59 \mu \mathrm{g} / \mathrm{dl})(\mathrm{p}=0.004)$. In a case-control study of well-nourished Bangladeshi children of age group 6-60 months with ALRI, Shakur MS, et $a l^{15}$ found that the mean serum zinc level was low in children suffering from ALRI $(90 \pm 51 \mu \mathrm{g} / \mathrm{dl})$ when compared to controls $(176 \pm 98 \mu \mathrm{g} / \mathrm{dl})$, $(p<0.05)$. Similar finding was also reported in the study by Kumar $\mathrm{S}$, et al ${ }^{13}$ which showed low serum zinc level in children between 2 months to 5 years with pneumonia compared to control group $(\mathrm{p}=$ 0.001). Other studies by Hussain AM, et $a l^{12}$ and Paneerselam $\mathrm{R}$, et $a l^{10}$ have also reported significantly low serum zinc levels in children with pneumonia when compared to healthy controls.

One explanation for the low serum zinc levels seen in cases of pneumonia might be an already existing zinc deficiency, which increases the susceptibility of a child to get pneumonia by impairing child's immunity ${ }^{19}$. Another explanation for the low serum zinc levels might be the shift of zinc from plasma to liver, said to be caused by cytokines released during acute phase response to infection ${ }^{20}$. The increased amount of intracellular zinc acts as a toxin to the engulfed pathogens and protects the cell by promoting production of neutralizing reactive oxygen and nitrogen species ${ }^{21}$. The mean serum zinc level $(53.0083 \pm 11.286 \mu \mathrm{g} / \mathrm{dl})$ was found to be decreased in the present study which resembles the results of the study by Hussain AM, et $a l^{12}$. This can be attributed to the mild to moderate zinc deficiency common in developing countries both due to inadequate intake of zinc in the diet as well as the high phytate content in cereal based diets which are popular in these countries which inhibits the absorption of zinc from intestine. A community based cross sectional study by Kapil $\mathrm{U}$, et $a l^{22}$ to estimate the prevalence of zinc deficiency among Indian children 6-60 months of age showed an overall prevalence of $43.8 \%$. Current evidence suggests that there is no role for the prescription of zinc as an adjunctive therapy for paediatric pneumonia. Haider BA, et $a l^{23}$ conducted a systematic review of 4 randomized control trials (RCTs) which analysed the beneficial effects of zinc as adjuvant therapy in addition to antibiotics in children aged 2 to 59 months of age and found that zinc supplementation did not confer any significant benefit on the clinical recovery of patients in terms of time-to-recovery from tachypnoea (respiratory rate $>50$ breaths per minute) and time-to-recovery from chest indrawing or on the time-to-hospital discharge. However, several studies have reported a beneficial effect of zinc supplementation in preventing paediatric pneumonia $^{4,24}$. A meta-analysis of 10 RCTs comparing the effects of zinc versus placebo on the incidence of ALRI in children $<5$ years showed that zinc supplementation reduced the incidence of
ALRI by $35 \%(95 \% \text { CI } 18 \% \text { to } 48 \%)^{25}$. Further RCTs are needed to identify the target population of children who might benefit from zinc supplementation and its optimal mode of community-based delivery (i.e. fortification, supplementation), dose and duration.

The study had some limitations. The diagnosis of ALRI, including pneumonia, was based on clinical symptoms and pneumonia was categorised further into different grades based on WHO classification only; radiological features were not considered for severity or diagnosis. Correlation between nutritional status, dietary intake and serum zinc levels could not be done in this study.

\section{Conclusions}

The mean serum zinc level was low in children with ALRI who developed tachypnoea, tachycardia and low oxygen saturation in room air which are predictors of severity of illness. The mean serum zinc levels were also low in children with different grades of pneumonia when compared to children with WALRI / bronchiolitis and in children with severe pneumonia when compared to those with pneumonia.

\section{References}

1. Skalny AV, Rink L, Ajsuvakova OP, Aschner M, Gritsenko VA, Alekseenko SI et al. Zinc and respiratory tract infections: Perspectives for COVID-19 (Review). International Journal of Molecular Medicine 2020; 46(1): 17-26. https://doi.org/10.3892/ijmm.2020.4575 PMid: 32319538 PMCid: PMC7255455

2. Gammoh NZ, Rink L. Zinc in infection and inflammation. Nutrients 2017; 9(6): 624.

https://doi.org/10.3390/nu9060624 PMid: 28629136 PMCid: PMC5490603

3. World Health Organisation. Pneumonia. Available from:

https://www.who.int/en/news-room/factsheets/detail/pneumonia [Accessed 24 Jun 2020].

4. Roth DE, Caulfield L, Ezzati M, Black RE. Acute lower respiratory infections in childhood: opportunities for reducing the global burden through nutritional interventions. Bulletin of the World Health Organisation 2008; 86: 356-64. https://doi.org/10.2471/BLT.07.049114 PMid: 18545738 PMCid: PMC2647440 
5. World Health Organisation. Pocket book of hospital care for children: guidelines for the management of common illnesses with limited resources. $2^{\text {nd }}$ ed. Geneva: World Health Organisation; 2013.

6. Rady HI, Rabie WA, Rasslan HA, El Ayadi AA. Blood zinc levels in children hospitalized with pneumonia: A cross sectional study. Egyptian Journal of Chest Diseases and Tuberculosis 2013; 62(04): 697-700.

https://doi.org/10.1016/j.ejcdt.2013.09.020

7. Kliegman RM, Blum NJ, Shah SS, St.Geme JW, Tasker RC, Wilson KM, Behrman RE. Nelson Textbook of Pediatrics. $21^{\text {st }}$ ed. Philadelphia: Elsevier; 2020. Chapter 81, Pediatric Emergencies and Resuscitation; p 530.

8. World Health Organisation. Oxygen therapy for children: a manual for health workers. Geneva: World Health Organisation; 2016.

9. Akhtar S. Zinc status in South Asian populations--an update. Journal of Health Population and Nutrition 2013; 31(2):13949.

https://doi.org/10.3329/jhpn.v31i2.16378

PMid: 23930332 PMCid: PMC3702335

10. Panneerselam R, Marimuthu B. Serum zinc level in children admitted with pneumonia at tertiary care children's hospital. International Journal of Scientific Study 2016; 4(1): 283-5.

11. Kumar DE, Annamalai T, Ahmed SM, Sundari S. Plasma zinc levels in normal and malnourished children with lower respiratory tract infection from 2 months to 5 years of age. International Journal of Contemporary Pediatrics 2019; 6:1285-8. https://doi.org/10.18203/23493291.ijcp201 92029

12. Hussain AM, Saldanha PRM, Sharma D, Pandita A, Yachha M, Tariq M. Estimation of zinc levels in children with lower respiratory tract infections: a prospective observational study from India. Pediatrics and Neonatal Nursing Open Journal 2016; 2(3): 91-8.

https://doi.org/10.17140/PNNOJ-2-115

13. Kumar S, Awasthi S, Jain A, Srivastava RC. Blood zinc levels in children hospitalized with severe pneumonia: a case control study. Indian Pediatrics 2004; 41: 486-91.

14. Shivalingaiah M, Ramaraj SM. Serum zinc levels in children hospitalized with pneumonia - A cross-sectional study. Indian Journal of Child Health 2019; 6(10): 545-7.

https://doi.org/10.32677/IJCH.2019.v06.i1 0.007

15. Shakur MS, Malek MA, Bano N, Islam K. Zinc status in well-nourished Bangladeshi children suffering from acute lower respiratory infection. Indian Pediatrics 2004; 41: 478-81.

16. Ibraheem RM, Johnson AB, Abdulkarim AA, Biliaminu SA. Serum zinc levels in hospitalized children with acute lower respiratory infections in the north-central region of Nigeria. African Health Sciences 2014; 14(1):136-42.

https://doi.org/10.4314/ahs.v14i1.21

PMid: 26060470 PMCid: PMC4449050

17. Pushpa, Lohano M, Memon $M$. Association of serum zinc level with severe pneumonia in children. Pakistan Journal of Nutrition 2009; 8:1873-6. https://doi.org/10.3923/pjn.2009.1873.187 6

18. Arica S, Arica V, Dag H, Kaya A, Hatipoglu S, Fenercioglu, A et al. Serum zinc levels in children of 0-24 months diagnosed with pneumonia admitted to our clinic. International Journal of Clinical and Experimental Medicine 2011; 4(3): 227-33.

19. Shankar AH, Prasad AS. Zinc and immune function: the biological basis of altered resistance to infection. American Journal of Clinical Nutrition 1998; 68(suppl.): 447S-63S.

https://doi.org/10.1093/ajen/68.2.447S

PMid: 9701160

20. Sazawal S, Black RE, Jalla S, Mazumdar S, Sinha A, Bhan MK. Zinc supplementation reduces the incidence of acute lower respiratory infections in infants and preschool children: a doubleblind, controlled trial. Pediatrics 1998; 102:1-5. https://doi.org/10.1542/peds.102.1.1 PMid: 9651405 
21. Maywald M, Wessels I, Rink L. Zinc signals and immunity. International Journal of Molecular Sciences 2017; 18: 2222.

https://doi.org/10.3390/ijms18102222

PMid: 29064429 PMCid: PMC5666901

22. Kapil U, Jain K. Magnitude of zinc deficiency amongst under five children in India. Indian Journal of Pediatrics 2011; 78(9):1069-72.

https://doi.org/10.1007/s12098-011-0379-

$\mathrm{Z}$

PMid: 21318393

23. Haider BA, Lassi ZS, Ahmed A, Bhutta ZA. Zinc supplementation as an adjunct to antibiotics in the treatment of pneumonia in children 2 to 59 months of age. Cochrane Database Systematic Reviews 2011; 2011(10): CD007368. https://doi.org/10.1002/14651858.CD0073 68.pub2

PMCid: PMC7000651
24. Lassi ZS, Moin A, Bhutta ZA. Zinc supplementation for the prevention of pneumonia in children aged 2 months to 59 months. Cochrane Database Systematic Reviews 2016; 2016(12): CD005978.

https://doi.org/10.1002/14651858.CD0059 78.pub3

PMid: 27915460 PMCid: PMC6463931

25. Roth DE, Richard SA, Black RE. Zinc supplementation for the prevention of acute lower respiratory infection in children in developing countries: metaanalysis and meta-regression of randomized trials. International Journal of Epidemiology 2010; 39(3): 795-808. https://doi.org/10.1093/ije/dyp391 PMid: 20156999 